\title{
Power Relation In Memoirs Of Geisha And The Dancer
}

\author{
Mundi Rahayu \\ Lia Emelda Siti Aisyah \\ English Language and Letters - Faculty of Humanities \\ UIN Maulana Malik Ibrahim Malang \\ Jl. Gajayana No. 50 Malang \\ mundi_rahayu@yahoo.com
}

\begin{abstract}
This article aims at comparing the ideas of power relation between the main female character and "Mother" in Arthur Golden's Memoirs of Geisha and Ahmad Tohari's The Dancer. These two novels share the same main female character of traditional entertainers, as a Japanese geisha and a Javanese traditional dancer, respectively. As an entertainer in the traditional sphere, they are bounded with the other women and build close interaction as well as power relation with them who are called "Mother" in the Geisha and "ronggeng shaman" in The Dancer. The power relation between them are unique and dynamics. This is analyzed through Foucault's theory of power. The result of the analysis shows that the power relation is not stable, and the power practiced by each of them is influenced by the symbolic capital and economic capital they have. The negotiation and contestation come up between the actors in daily practices as geisha and the mother, as the "ronggeng" and the shaman. As the entertainers, the geisha and "ronggeng" build and shape their body and performance to attract men. This geisha and ronggeng culture reproduce many other cultural product such as "mizuage" in geisha, and "bukak klambu" in "ronggeng" both of which refer to the same thing, selling the woman's virginity to the highest bidder. In geisha it is used to benefit the Mother of Okiya and no rebellion of the geisha. On the other hand, Srintil does rebellious action in this "bukak klambu" occasion. There seems to be different message from these two novels, The Dancer
\end{abstract}


is much more questioning the norms covering the "ronggeng" tradition while the Memoirs of Geisha tends to be accepting the geisha tradition as what it is.

Keywords: power relation, geisha, ronggeng, norms.

\begin{abstract}
Abstrak
Artikel ini bertujuan untuk membandingkan relasi kuasa antara karakter utama perempuan Geisha dan "Mother" dalam Memoirs of Geisha dan Srintil, penari ronggeng dan Nyi Kartareja (dukun ronggeng) dalam The Dancer karya Ahmad Tohari. Kedua novel ini dibandingkan karena keduanya sama-sama mempunyai karakter utama perempuan muda penghibur, geisha dan ronggeng, dalam budaya hiburan tradisional. Sebagai penghibur, keduanya sama-sama terkait erat dengan tokoh perempuan lain yang disebut "Mother" dalam Memoirs of Geisha and Nyai Kartareja dalam The Dancer. Relasi kuasa di antara keduanya sangat unik dan berjalan secara dinamis. Relasi kuasa inilah yang dianalisis dengan menggunakan teori kuasa Foucault. Hasil penelitian ini menunjukkan bahwa relasi kuasa di antara keduanya berjalan tidak tetap, kuasa yang dijalankan oleh masing-masing tokoh dipengaruhi oleh modal simbolik dan modal ekonomi yang dimiliki. Negosiasi dan kontestasi muncul di antara tokoh-tokoh tersebut dalam praktik sehari-hari, dalam relasi Sayuri sebagai geisha dan "mother", dan antara Srintil si ronggeng dan dukun ronggeng. Sebagai geisha dan ronggeng, para perempuan ini membentuk tubuh dan penampilannya untuk menarik dan menghibur laki-laki. Budaya geisha dan ronggeng ini mereproduksi berbagai kultur lainnya seperti mizuage dalam geisha, dan "bukak klambu" dalam ronggeng, yang keduanya sama-sama bermakna menjual keperawanan perempuan kepada penawar tertinggi. "Mother" pemilik Okiya diuntungkan oleh praktik ini, di sisi lain, Srintil berhasil mengelabuhi orang lain dalam peristiwa "bukak klambu". Muncul pesan yang berbeda dari kedua novel ini, dalam The Dancer norma-norma dalam tradisi "ronggeng" dipertanyakan sementara Memoirs of Geisha cenderung menerima tradisi geisha sebagaimana adanya.
\end{abstract}

Kata kunci: relasi kuasa, geisha, ronggeng, norma. 


\section{Introduction}

In our daily interaction power relation in unavoidable, it exists between teacher and student, husband and wife, doctor and patient, policeman and policewoman, and any other human relation. Power is not exclusively possessed by government or structural position. To understand the power that is omnipresent, Foucault (1988) develops a model of understanding the power that operates through network around the institution, exists in social interaction and operated by anybody. Power relation is more sublime than we realize. Foucault differentiates between the power relation as "strategic games between liberties" and the other two kinds of power relation, domination and government (Foucault 1988: 19). In general, the concept of power as "the strategic games among the liberties" becomes the core to understand power.

This research aims at portraying the power relation that operates between the traditional female artists, geisha and "ronggeng" (dancer), and the "mother" refering to the woman who has close relationship to the artists. In the novel Memoirs of Geisha by Arthur Golden, the woman is called Mother, a woman who is in charge in the Okiya, a geisha house. In Ahmad Tohari's The Dancer, the woman is Nyai Kartareja, a "ronggeng" shaman whose roles is constructing and nurturing a ronggeng as well as a managing the "ronggeng" business.

Memoir of Geisha tells the readers about the struggle of a little girl, Chiyo, to be a geisha. At very young age, she was sold to the Okiya. As a little girl she has to be discipline and loyal to the other older women in the house, Mother, Granny, Hatsumomo, and a girl named Pumpkin. Chiyo tries to resistant against Mother but she is not successful, until the 
coming of a senior and reputable geisha, Mameha, who wants to train and shape her to be a reputable geisha.

The Dancer is the English version of Ronggeng Dukuh Paruk written by Ahmad Tohari. This novel tells us about the struggle of a poor little girl to become a traditional Javanese dancer called ronggeng who lived in remote areas in Java under the turmoil of political context of mid 1960s. She was constructed as a legitimate ronggeng with particular ritual guided by Nyai and Ki Kartareja, the "ronggeng" shaman. The power relation between Srintil and Nyai Kartareja is dynamics and complicated. Many times Srintil is able to be resistant, and liberate herself from this "ronggeng" world, but at the end this "ronggeng" leads into tragic fate.

In analyzing the power relation between the female characters in the two novels, the researcher considers the comparative literature approach. According to Damono (2009:1) comparative literature studies two or more literary works from different countries, languages or different texts. Wellek and Warren (1989:47), also stated that practically comparative literature is a study about the relation of two literary works or more, to find the shared problem or conflict in the literary works. The novels in this study are The Dancer that portrays the Javanese culture of ronggeng.

As an entertainer, the dancer or "ronggeng" not only dances but she also serves as sexual worker. In the geisha culture, it is more complicated in the sense that the geisha has to be able many skills such as dancing, playing traditional music instrument as well as serving in the tea party. The geisha is limited in her relation with men, only a man who can buy her in the highest bidding can enjoy sexual relationship with her. 
A geisha is allowed to have sexual relationship to the man who permanently give her much money and wealth, such a man is called danna. So, a geisha is not allowed to have sexual relationship for anybody but only for a particular man who pays the most.

Foucault's theories on power is closely related to the control system. Foucault said that in capitalist society control is not operated from outside, instead the control system prevails upon the individual to self-monitor and self-discipline themselves by promoting norms and naturalizing them so that the individual will feel compelled to conform in order to gain acceptance and success.

\section{Discussion}

\section{Power Relation between Sayuri and Mother of Nitta Okiya}

Memoirs of Geisha tells the readers about Chiyo, a little girl of a very poor family who is sold by her father and she ends in the Nitta Okiya, a geisha house. In the Okiya, little Chiyo learns many things especially from the most commanding persons, Granny and Mother, the owner of the Okiya, the current geisha in the Okiya, Hatsumomo, and other little girl in the okiya called Pumpkin. The power relation between Chiyo and Mother of Okiya comes up along the story, and it will be the focus of this analysis in this article. The relation between them is a very dynamic one, involving negotiation and contestation between them.

Mother of the Okiya has biggest power to control anything, especially the business that is kept alive in the house, the business of geisha. Mother, used to be a geisha when she was young, has to manage the geisha, making her as a money machine. She is the most experienced woman in the house to make the geisha popular and draws much money 
from the service the geisha does in the tea house and from men who likes her. To run the business of geisha, Mother of the Okiya also thinks about the regeneration of the geisha. She really understands that a geisha can not be a geisha anymore when she is older. She has to think the next generation of geisha in the house so that the Okiya and the people inhabiting it will be survive and enjoy the comfortable life. For that regeneration purpose, Mother buys little girls to work as maid in the house before she is selected to be sent to school of geisha if she is lucky, otherwise she will be a maid forever. The geisha culture is reproduced in this way, it is selected from the little girls in the Okiya and then the geisha-to be is sent to school where the girls learn how to serve in the tea party, playing musical instrument, dancing, singing as well as how to make a good conversation, all of which is aimed at entertaining the men in the tea house.

In such reproduction of cultural system, a geisha seems to be the highest position or the best reward for the girls. A geisha, depends on her beauty and popularity, is the only commodity of the Okiya. The Okiya Mother will get much money from a geisha since the first time a girl is declared as a geisha, followed by many rituals and activities in which the geisha is the main player.

In this novel, the Okiya is portrayed as a house of geisha for many generation. Granny and Mother were used to be a geisha, and Hatsumomo is the current geisha in the house. An Okiya only has one geisha, who has to prepare herself with adorable make-up, many accessories, and kimono before going to the tea house. Her main job is entertaining the customers, mostly wealthy men coming to the tea house. In doing her job she is completed with the skills of tea party, dancing, 
playing traditional music instrument, and of course the skill of acting and speaking that pleases the men.

For her service and relationships with the men, the geisha gets much money and wealth. The more popular a geisha the more money she will get. Hatsumomo has to give the money she gets to Mother as the manager of Okiya. As a return, mother prepare all the geisha's necessities, meals, best bedroom in the house, the best collection of Kimono and other accessories as a geisha, as well as managing the relationship a geisha has to make or allowed to make.

Since the first time, Chiyo has been introduced with the structure of power in Okiya, on the top of the pyramid is Granny, and Mother, and below them is Auntie, and the geisha, Hatsumomo. On the lowest level is Pumpkin, a little girl as a maid who has to serve many things for the geisha and do a lot of house chores everyday. As the geisha, Hatsumomo enjoys many facilities in the house to make her happy and comfortable. All of the maid have to serve her in day to day activities. Chiyo as a new comer posts in this lowest rank of structure. Consequently she has no other choice but to obey all the rules from the other elder women, especially Mother.

"Well, little girl," Mother told me, "You are in Kyoto now. You'll learn to behave or get a beating. And it's Granny gives the beatings around here, so you'll be sorry. My advice to you is: work very hard, and never leave the okiya without permission. Do as you're told; don't be too much trouble; and you may begin learning the arts of a geisha two or three months from now. I didn't bring you here to be a maid. I'll throw you out, if it comes to that." (Memoirs of Geisha p. 43)

The norms is made clear, that someone who wish to be a geisha should obey all the rules and on the contrary, who does not obey the rules 
will get beating and will not achieve the highest position of geisha. Paragraph above shows the power of which Mother has, stated in command, prohibition, and threat to an obedient Chiyo. Chiyo learn that the norms is that she has to work hard, never leave the Okiya without permission, does not make any troubles, and the reward is being sent to school to be a geisha.

Mother had told me I could begin my training within a few months if I worked hard and behaved myself. As I learned from Pumpkin, beginning my training meant going to a school in another section of Gion to take lessons in things like music, dance, and tea ceremony. All the girls studying to be a geisha took classes at this same school. I felt sure I'd find Satsu there when I was finally permitted to go; so by the end of first week, I'd made up my mind to be as obedient as a cow following along on a rope, in the hopes that Mother would send me to the school right away. (Memoirs of Geisha p. 45)

However, since a very young age, Chiyo has "capital" that rarely possessed by the other girl, her very beauty eyes. All the people recognize it, but they did not appreciate it explisitly, instead, Hatsumomo thinks this as a potential rival. As the only geisha in the Okiya, Hatsumomo assumes the biggest power and she always strengthens her power. In encountering with the potential rival, little Chiyo, Hatsumomo inflicts her power against Chiyo.

"But if you touch them," she said, "they'll start to smell like you. And then the men will say to me, "Hatsumomo-san, why do you stink like an ignorant girl from a fishing village?' I'm sure you understand that, don't you? But let's have repeat it back to me just to be sure. Why don't I want you to touch my make up?" I could hardly bring myself to say it. But at last I answered her. "Because it will start to smell like me.” (Memoirs of Geisha p. 48) 
Hatsumomo seems to highlight her position in front of Chiyo, to declare her status as prestigious geisha and her top performance. The identity emphasized by Hatsumomo also functions as the warning that Chiyo not to close to her position, and as a threat for Chiyo not to ever think that she would be able to rival her. Hatsumomo builds clear gap between her and Chiyo.

I won't say that I believed her; but of course, Hatsumomo had the power to make my life miserable in any way she wanted. I had no choice but to obey. (Memoirs of Geisha p. 72)

Chiyo has ever realized how much power Hatsumomo has in the Okiya beside Granny and mother. Hence, she has no choice except to submit to Hatsumomo. Even when Hatsumomo does mistake, such as having and bringing her boyfriend to the Okiya some day, nobody, including Chiyo, tells Mother, Granny, or Auntie. It happens because Hatsumomo always has a trick to hide her action. She has power to convince Mother, Granny, and Auntie in order to conceal her behavior.

Chiyo's opportunity to be a geisha has lost since she has big problem with Mother. When Chiyo tries to run away passing the roof, she falls down and have to come back to the Okiya with her broken arm. Since then, Mother decided not to resume her lessons again, and Chiyo will pay all her debts by becoming her maid, not to be a geisha. However, her life changes since she meets Chairman Iwamura, an owner of Iwamura Electric, of whom she falls in love with. This encourages her to build a purpose in her life, to be a geisha.

If I were a geisha like the one named Izuko, I thought, a man like the Chairman might spend time with me. I'd never imagined myself envying a geisha. I'd been brought to Kyoto for the purpose of becoming one, of course; but up till now I'd have run away in an 
instant if I could have. Now I understood the thing I'd overlooked; the point wasn't to be a geisha, but to be one. To become a geisha... well, that was hardly purpose in life. But to be a geisha... I could see it now as a stepping-stone to something else. (Memoirs of Geisha p. 113-114)

The norms introduced to Chiyo results in Chiyo's obedience but this obedience becomes a strategy that benefit her, as she says, "I'd made up my mind to be as obedient as a cow following along on a rope, in the hopes that Mother would send me to the school right away". This obedience is also the strategy which Chiyo uses to get Mother's trust. She keeps the plan to find the chance of looking for her sister and plan to run away together. However, when Mother finds Chiyo tries to run away, she stops all the investments of Chiyo's training. Mother decides to make Chiyo becoming her slave, not as a geisha.

Chiyo's dream to be a geisha comes true with the coming of Mameha, one of a few successful geishas in Gion. Mameha is also Hatsumomo's rival. Mameha opens the chance for Chiyo to be a geisha, by arranging a negotiation with Mother so that Mother allows Chiyo to go to school.

"Now, Chiyo, stumbling along in life is a poor way to proceed. You must learn how to find the time and place for things. A mouse who wishes to fool the cat doesn't simply scammer out of its hole when it feels the slightest urge. Don't you know how to check your almanac?" (Memoirs of Geisha p. 126)

Mameha is smart enough and her saying that "A mouse who wishes to fool the cat doesn't simply scammer out of its hole when it feels the slightest urge " means that, it is not simple to win in a war; it needs a strategy to fight against Mother decision and persuade her to resume 
Chiyo's training. The negotiation results in the agreement between Mameha and Mother, that Mameha will bring Chiyo to her apartment and train her as her younger sister, to be a geisha. She promises that Chiyo will repay all her debts by the age of twenty. This makes Mother surprised and she does not believe Chiyo can do it because there is no geisha can be success and repay all the debts into Okiya by the age of twenty in Gion yet.

"After all, in Chiyo's case, with you as her older sister, her debts will only grow worse before they get better." Mother wasn't just talking about my lesson fees; she was talking about fees she would have to pay to Mameha. A geisha of Mameha's standing commonly takes a larger portion of her younger sister's earning than an ordinary geisha would. (Memoirs of Geisha p. 134)

Finally, Mother and Mameha also agree on the amount of money will be got by Mameha if she can make Chiyo succeed by the age of twenty and nothing if she fails.

"You're quite right," said Mother. "Thirty percent is a bit low. I'll offer you double, instead, if you succeed." "But nothing if I fail" (Memoirs of Geisha p. 135)

Mameha's negotiation with Mother about Chiyo shows that the geisha or a geisha to be is a real commodity of which value is determined by the power of cultural reproduction. Mameha shows herself the agent of cultural reproduction who has the symbolical capital in the form of expertise to train a geisha to be in a particular time and ensure the success of the geisha. With the asisstance of Mameha Chiyio gains her cultural capital and symbolic capital to be a successful geisha, named Sayuri. In creating the geisha name, Mameha has to go to her fortune teller to make sure that the name is a good one. 
The cultural practice of geisha that is reproduced in this novel is the practice of mizuage, meaning selling the virginity of the apprentice geisha to the high bargainer. The ability to find the highest bidder will build geisha's reputation. Mameha works hard to set the rules for finding the highest bidder and she is successfull having Nobu and Dr. Crab as the highest bidder and this is announced and registered in the town tax administration as the highest price for the mizuage in Gion Y11,500. By having that money, Mameha is able to pay back Sayuri's debt to Mother and this means that Mameha wins the bet, paying back Chiyo's debt before twenty years old, at that time of mizuage, Sayuri is eighteen years. Sayuri realizes this facts, that her values is determined by the ability to earn money.

It goes without saying that this is why she adopted me. The fee for my mizuage was more than enough to repay all my debts to the okiya. If Mother hadn't adopted me, some of that money would have fallen into my hands - and you can imagine how Mother would have felt about this. When I became the daughter of the okiya, my debts ceased to exist because the okiya absorbed them all. But all of my profits went to the okiya as well, not only them, at the time of my mizuage, but forever afterward. (Memoirs of Geisha p. 279)

The reproduction of mizuage practice can be seen as an important meaning for a geisha like Sayuri, that it is the way to earn much money at one time. This mizuage can be done only once in a life time, that is why the geisha prepares herself much and mizuage is arranged seriously. This amount of money is able to pay the geisha's debt to the Okiya, consequently the Mother of Okiya will adopt her as daughter because of valuing her ability of making money in the future. As the new geisha in the Okiya, Sayuri will get many facilities in turn of her big contribution 
to the Okiya. The amount of price in the mizuage also sets the reputation of the geisha in her future profession. All of these make Sayuri hold new power in her relation to Mother of Nitta Okiya. A successful mizuage, a reputable geisha gives her symbolical and economic power in the Okiya and the geisha communities.

\section{The Power Relation between Srintil and Nyai Kartareja}

In The Dancer the power relation between Srintil, the young female traditional dancer called "ronggeng", and her "ronggeng shaman' is built a unique way. Srintil, at first did not know about her skill of dancing. It is the shaman, Ki Kartareja and his wife, Nyai Kartareja who found out her ability dancing through a specific ritual in the grave of $\mathrm{Ki}$ Secamenggala, the late elder in the Dukuh Paruk village whose grave is considered as sacred. In that grave, at one night they asked Srintil to dance, and Srintil proves herself to be able to dance, to be "ronggeng". The shaman decides that Srintil is proven to hold "indang ronggeng", a spiritual ability to be a ronggeng. It is the knowledge in the village that a ronggeng can not be trained, a ronggeng has to hold "indang ronggeng" and this is the power of the shaman to prove and make decision whether or not a girl hold "indang ronggeng".

The fact that Srintil, a naïve little girl, was able to imitate a ronggeng dancer's style with considerable skill would not have come as a surprise to anyone from Paruk. in the hamlet there was a powerful belief that a true ronggeng dancer was not the result of teaching. No matter how she was trained, a young woman could not become a ronggeng dancer without being possessed by indang spirit. In the world of ronggeng, the indang was referred as a kind of supernatural godmother. (The Dancer, p. 8) 
"Ronggeng" is the a dancer in traditional Java whose role is not only entertaining people in a particular occasion, but also an agent of change. In this novel it is told that a ronggeng is a ticket to make the village prosperous. The village, Dukuh Paruk, in Central Java in the mid 1960s, was a poor village, the soil was not fertile enough and the people have no other economic access. No infrastructure built in the village, it is in remote area and no big road and other public facilities built. It is narrated in the novel that Srintil's parents were committed suicide after the "tempe bongkrek" (a kind of tempe made of soy and coconut pulp/coconut nucifera) they made caused some people in the village dead.

This fact showed how poor and miserable the people in the village were. Because of no educationtal access and long poverty they experienced, the people in the village perceived that the poverty was seen as the consequences of the lack of ronggeng in the village. That is why the elders think to find out the ronggeng to live up the village.

For Srintil, being a "ronggeng" is the way to pay her parents" guilty to the people in Dukuh Paruk. Moreover, Srintil is able to prove to the shaman that she hold the "indang ronggeng". She is then announced as the ronggeng by the shaman, Ki and Nyai Kartareja. The "ronggeng" is accompanied by a team of traditional music player, one of them is Sarkum, an old and blind kendang player who is able to "smell" the indang ronggeng held by Srintil, and he happily accompanies the dancer because he is sure that Srintil is the legitimate ronggeng.

As a dancer, Srintil is managed by the shaman, Ki and Nyai Kartarejo in any performance she has to make. It is the shaman who make sure that the performance is safe and runs well. Nyai kartarejo 
functions as the manager for Srintil, by managing all the schedule for the performance and any man who wants to be accompanied by Srintil. It is Nyai Kartareja who manage the money and all income of the dancer.

For Nyai Kartareja, Srintil is like a money machine. It is Nyai Kartareja who makes decision on many business related to Srintil's job. Being a ronggeng is a big sacrifice for Srintil because she has to accept the request of many men who want her, including making sexual relation. $\mathrm{Ki}$ and Nyai Kartareja are experienced ronggeng shaman, so that it easy for them to train Srintil as the ronggeng for her performance. Nyai Kartareja has more job, that is managing the men who take the turns to sleep with Srintil. Srintil obey whatever Nyai Kartareja wants because Nyai has the knowledge of anything about a ronggeng and she also applies a magic practice to influence Srintil for many purposes all of which is beneficial for Nyai.

The power of Nyai Kartareja in deciding the ronggeng practice is also revealed in the practice of bukak klambu, literally means "open the veil" and in the ronggeng practice it means a competition for men to obtain the dancer virginity. For this big occasion, Kartareja was busy preparing for the bukak klambu. He travelled far away, spreading the news about this event expecting that the bidder is the most wealthy man, and he decided the winner, who gave him a gold piece.

"I have decided that the time will be next Saturday," said Kartareja, addressing a large group of men at the market. (The Dancer, p. 52)

Even though Srintil disagree with that decision, nothing can be done by Srintil except obeying Ki and Nyai Kartareja's decision. Mr. and Mrs. Kartareja use all tricks to make Srintil submit to their decision. It is 
important for the guardian to determine who will get Srintil's virginity, it because the income will come into Mr. and Mrs. Kartareja's family. In fact, there are two men who offer for Srintil's virginity.

One of them is Dower who brings two silver and a big female buffalo, and the other one is Sulam who brings a gold piece. Seeing those offers, Mr. and Mrs. Kartareja make a trick, receiving both offers (the gold and silver as well as bufallo), but he manipulates it by arranging competition of drinking ciu (traditional alcoholic beverage made of fermented coconut water) for them and the winner will sleep with Srintil. Both of them drink much ciu so that they does not fully realize what they do.

On the other hand, Srintil really does not want to have "bukak klambu" after knowing that it means she has to sleep with the man, the highest bidder and makes a sexual intercourse with the man she does not familiar with. Realizing this crucial moment, in which Srintil can not avoid and safe herself, she decides to give her virginity to Rasus, her childhood friend that Srintil actually loves much. At the night before the "bukak klambu", Srintil gave herself to Rasus, the man she loves. This action taken purposedly by Srintil shows her rebellious nature, and she feels this is the best thing to do, at least she is able to make her own decision with her body at least once without Kartareja's notice.

"I hate this. I'd rather give myself to you, Rasus. You can't turn me away like you did this afternoon. This isn't a graveyard and we're not going to be cursed. You do want to, don't you?" (The Dancer, p. 77-78)

It is said by $\mathrm{Mr}$ Kartareja that Bukak klambu is the last requirement to be a ronggeng, and by passing that night Srintil has been becoming a 
true ronggeng. As the ronggeng does not only perform dancing, but she is also a sexual worker, it is Mr. and Mrs. Kartareja's benefit to get much money selling Srintil as commodity. It is the reason why it is important for them to keep her under their control. On the other hand, Srintil begins realizing her feeling into Rasus and her position which is under Mr. and Mrs. Kartareja's control. Sometimes, she refuses Mrs. Kartareja's order, but the Kartarejas do everything to keep her into their control, including breaking Srintil's feeling into Rasus.

Mrs. Kartareja realized that she had to do something to break the love that bound Srintil to Rasus. She decided to try some magic. She found an unhatched egg which had been left to rot in the chicken coop and secretly buried it under one corner of Srintil's bedroom. Over this spot she recited a spell to break the love. (The Dancer, p. 122)

It is Kartarejas' interest to keep Srintil as a ronggeng under their control, implying that Srintil is not allowed to fall in love with Rasus or other men. Because, if Srintil decides to get married, her status as a ronggeng is finished. Consequently, Kartarejas' income will be over. The contestation between Kartarejas and Srintil happens silently many times. The first time is the incident of bukak klambu, in which Srintil is actually not a virgin anymore because she has given herself to Rasus without Kartareja's notice.

How does Srintil negotiate her position and struggle for her own interest? This is interesting because Srintil who has the symbolic capital as a ronggeng in fact does not have power to decide her own destiny. She is stil under Kartarejas, with the symbolical power as shaman. Many times Nyai Kartareja do shamanic practice to make Srintil obey to them. Many times Srintil refuses to perform dancing or entertaining men in the 
bed. She wants to have freedom of her self and her feeling, but Mr. and Mrs. Kartareja do not stop forcing her to perform, moreover to receive the guest. Nyai Kartareja blames Srintil every single rejection from Srintil to the man who wants to be with her.

After political disturbances attacked Dukuh Paruk, Srintil quits being a ronggeng. She and all people of Dukuh Paruk are accused of involving in the political turmoil. All people fall into detention. However trying to able to survive and prosper after the turmoil, Mrs. Kartareja persuades Srintil again to be a "ronggeng". "I just want to talk about my situation. In the past, I suffered, but not the way I'm suffering now. In the past, to tell you the truth, I was always able to follow your wishes. But now, young lady, it's a matter of whether there will be food on my table. So, I have a proposal: in return for the help I gave you in the past I would like you to give me the opportunity to join you in a better life." (The Dancer, p. 322)

The power relation between the Kartarejas and Srintil shows that at the beginning, because of the symbolical capital as "ronggeng shaman" it is Kartarejas' power to determine and dominate Srintil. It is Kartarejas' work that makes Srintil a ronggeng, through the discourse of "indang ronggeng", and other rituals such as "bukak klambu". The knowledge of Kartarejas produces the ronggeng and ronggeng as cultural product reproduces the culture in Dukuh Paruk in such a way that people acknowledge and agree to the ronggeng practice. Personally, through persuasion and order, Kartarejas maintain their control over Srintil.

However, the Kartarejas' power over Srintil and over the community is not a fixed, stable one. The power is destabilized through many factors, such as internal relationship factor (Srintil's resistant) and 
sociopolitical factor (political turmoil happens involving the people of Dukuh Paruk). These incidents, micro and macro, happen and destable the power domination of Kartarejas to Srintil.

Srintil learns much from sufferings and happiness she experienced during her times as a ronggeng. During this time as ronggeng, she learns how to be an obedient girl for Kartarejas so that she becomes a popular ronggeng, under Kartarejas' guidance and training, control and order. As a girl to be a ronggeng, she obeys whatever Kartarejas say and order to her. The Kartarejas build the power through the discourse of ronggeng norms that Srintil and others have to obey.

The first discourse is that ronggeng is badly needed by the village of Dukuh Paruk to be prosperous, alleviating the poverty. This gives a feeling of proud for Srintil to be a ronggeng because she can pay her parents' mistakes in the past, giving back the feeling of being trust and honored by the people in the village. Moreover, being a ronggeng also gives a feeling of being a "hero" because the myth is the lack of ronggeng will make the village fall into long poverty. The meaning of being a hero, giving an important contribution to the village is a symbolical power built in Srintil's self. The power of Kartareja over Srintil in the beginning phase of being a ronggeng results in suffering of being opressed but at the same time Srintil realizes the power she gets and feels as a ronggeng.

The next disourse is the "indang ronggeng", which is only Kartareja who knows that Srintil has the "indang ronggeng" embedded in her. This power to determine the "indang ronggeng" possession is challenged by nobody. For Srintil this gives a feeling of being a sacred and special person, because this is rarely happen, so that only a chosen 
people has this spirit. This idea of "indang ronggeng" also legitimate the behavior of a ronggeng being the entertainer of community, and giving sexual pleasure to many men. Such sexual relation and practice is not accepted if it is done by women at large, but under the discourse of "indang ronggeng" this behavior is accepted by community. The power of being a sacred and chosen person in Srintil self is a proud, but at the same time it is felt by Srintil not as a comfortable one. She feels that it is not easy for her to be the possession of many men.

She feels that her existence is much determined by many interest, instead of her own interest. She wants to be a wife, a mother having a baby, but it is impossible as long as she is a "ronggeng", because a "ronggeng" is owned by the community, her body can be possessed by those who can pay. Nyai Kartareja and her husband do many efforts to maintain Srintil status as a "ronggeng" by prohibiting her to love someone or marry a man. Srintil marriage will put the business into the final end. Srintil obsession to be a wife is so strong and her innocence bring her to trust Bajus and she expects to be married by Bajus.

This leads into the tragedy, because Srintil can not bear the reality that Bajus does not love her at all and he even planned to sell Srintil to his boss. Srintil gets frantic, hysterical, and she can not grasp the reality anymore until the rest of her life.

The discourse of "bukak klambu" is a kind of practice that can be interpreted as a commodification of woman's body and sexuality that is legitimate for a "ronggeng". It is the "ronggeng shaman" who gets benefit from this practice because Mrs Kartareja will get much money from the highest bidder. For Srintil, realizing that this exploits her authority over her own body, she does resitance by giving herself to the 
man she loves, Rasus, before the night of "Bukak Klambu". This resistence is done successfully and it is a very meaningful moment for Srintil, feeling not guilty of giving her virginity to someone she loves, instead of giving it to the men of highest bidder.

\section{Conclusion}

The two novels, Memoirs of Geisha and The Dancer share some common things related to female traditional entertainer and their power relation built with the closest person. Sayuri or Chiyo has to struggle at the beginning of her life to survive in geisha house under the power of Mother. Srintil, an innocent poor village girl has to obey the shaman, Nyai and Ki Kartareja to be survived and to be a ronggeng. Both of the women, Sayuri and Srintil bear a duty to entertain and to make pleasure to the world, especially men. In doing this duty, they sacrifice by using their body as the main capital and supporting skills of the symbolic capital, such as dancing, singing, playing traditional instrument, but the most important thing is giving pleasure to the men. This shows that in the paternalistic world, men are in the power to be served, because of holding economic capital and the women use their symbolical power to make the men share their wealth.

The other important thing to note from these two novels is that both of the young women, Sayuri and Srintil are commodified and dominated by the women, Mother and Mrs Kartareja respectively, through controlling their body. As Foucault explains that body is the main target of power, the Mother of Nitta Okiya determines particular treatment for geisha's body to maintain the shape, beauty and the fabulous clothing and accessories as well as supporting ritual practice for the geisha to 
make sure that the woman will draw much men's attention and money. On the other hand, the mother of Okiya will beat the little girls who do not obey her. The punishment such as beating, prohibiting to go out and other physical punishment, all of which are aimed at the obedience of the girls to the norms enforced by the Okiya.

In the Memoir of Geisha, following her feeling, little Chiyo tries to resist to the Mother, by escaping from the Okiya. She is caught and got physical punishment such as beating and forbiding her to go to school. This punishment is paralyzing her because she is not sent to school so that her dream to be a geisha is faded away. However, Chiyo has a good fortune because there is a senior geisha, Mameha who comes to the Nitta Okiya and offer to Mother to train Chiyo to be a geisha. Mameha promised to Mother to pay back Chiyo's debt after Chiyo becomes a geisha. Mother agrees. Mameha does this becasuse of two reason, she got the order from the Chairman and she wants to defeat Hatsumomo, her rival, by making Chiyo the next geisha in the Okiya. Mameha is pretty sure of her success because she notices that Chiyo actually has a very beautiful eyes.

The important event of the woman commodification in the entertainment world is the selling and bidding of woman's virginity, which in geisha tradition is called mizuage. Those who has highest bidding will be the winner and enjoy the girl's virginity. Chiyo who turns to be Sayuri as a geisha, noted the highest bidder for her mizuage. Mameha professionally controls this game and defines the highest bidder for Sayuri's virginity. All of money that Sayuri can collect as a geisha can pay all her debt to the Nitta Okiya, the living cost while she is a slave in the Okiya. Moreover, Sayuri has economic and symbolic power as the 
most popular geisha and this fact changes her power relation to the Mother of Nitta Okiya.

Considering Sayuri's popularity as a geisha, Mother decides to adopt her as the daughter, implying that Sayuri becomes the only geisha living in Nitta Okiya, and Hatsumomo has to go away. This position makes Sayuri have bargaining power to Mother. After the external turmoil of second world war that devastates the lives of the community, including the Okiya lives, Sayuri and Mameha try to recover their life by once again becoming geisha on the request of Chairman and Nobu, their patron called danna, to help their company to be survived and developed after the war time. Finally Sayuri get a good chance to liberate herself and living as a free individual with her love.

This story of geisha seems to say that being a geisha in a paternalistic society is a "natural" thing. The novel portrays that the problems of the geisha is due to the poverty (Chiyo is sold by her very poor father) suffered by the families. The tradition of geisha is built under the norms of entertainer not prostitute so that a geisha is not allowed to make love relationship with any man (if the mother of the Okiya does not know).

A geisha is differentiated from prostitute, from the robe and the kimono, the geisha usually wears much more beautiful kimono than that worn by a prostitute. However this is contradict to the fact that the geisha also has danna, a patron, a man who support geisha with money and wealth, so that the geisha lives in a luxury. As the return the danna gets full service from the geisha in a longer periode of time.

The danna support all necessities of a geisha but he also determine and decide anything of the geisha whether the woman agree or not, such 
as what happens to Mameha who has to do abortion and she felt very sinful of killing her babies because her danna order this. This is a consequences of the geisha sells herself to the danna who buys her. The geisha is a commodity, and the author gives an ending that the geisha can liberate herself from this geisha life by the asistance of man with love. The geisha is represented as one of the way of life that respond to the social political context.

In The Dancer, Kartareja's domination over Srintil goes into the very basic control to the body and feeling, such as controlling how to be a "ronggeng", what kind of body movement (dance) a ronggeng has to create, to whom Srintil is allowed to make relation, to whom she has to make sexual relation, when and to whom Srintil has to give her very precious virginity through the "bukak klambu" ceremony. Srintil 's enjoyment as a ronggeng is also accompanied by her rebellion as her response to the "symbolic violence" she suffers.

Through the power domination that Kartareja exercise over Srintil, it is shown in this novel that Srintil is not totally obedient. She resists in many ways, according to her feeling and experience. Her resistence to have sexual relationship with the highest bidder in "bukak klambu" ceremony is done in silent. She subverts Kartarejo's plan by having sexual relation with Rasus, the young man she loves much. her love, before the night of "bukak klambu".

She just does it encouraged by her feeling of betraying Kartareja's domination. Srintil also maintains her feeling and wishes to be a wife and having baby. Kartareja can not crush her wishes. Srintil is obsessed to get married and be a wife that is on the contrary to the interest of Kartarejas who consider her as the economic assest. 
In the two novels, power relation between Sayuri and Mother, Srintil and Kartareja comes up in a dynamics. The enjoyment and facilities as the "women on the stage" for Sayuri and Srintil is obtained through strong effort, strugggle and suffering of domination and oppression. However, the young women are able to survive and get the position that is rarely enjoyed by common women. They built their power in many stages of their life that make the power domination changes.

Sayuri as the most popular geisha enjoys economic and symbolical power that makes her powerful in front of Mother of Okiya, and it is easy for her to win the wealthy man. After many incident of suffering and enjoyment, at the end of this novel, Sayuri gets much better life and she is able to liberate herself by the asistance of the man who loves her.

The good fortune of Sayuri does not happen to Srintil in The Dancer. Srintil enjoys much her life as a popular ronggeng and she makes the people around her prosperous, the Kartarejas, the music players, and people in the village get benefit though a little, from the popularity of Srintil as a ronggeng. The economy of the village is a little bit improved. The economic power that Srintil brings about, makes her powerful in front of Nyai and Ki Kertareja. Srintil power enables her to resist to the shaman in many ways, convertly and overtly.

However, Srintil's obsession to be a wife and a mother makes her insane and out of mind because her big obsession meets with an evil Bajus who plans to sell her instead of making her as wife. Srintil is shocked in facing the realities that is completely out of her mind. She refuses to grasp the reality that is too hostile and brutal for her. This is the end of Srintil life. 
Through this tragedy, it seems that the author of The Dancer wants to send message that the life of a ronggeng is not a good, normal life to choose because this life is based on the irrational norms and leads to the commodifying women and sexuality in such vulgar ways. The ronggeng life is the promiscuous one that need to be abolished as revealed in this novel. This "ronggeng" culture is also susceptible to the political power that seeks to spread its influence in the villages.

Although Srintil is able to liberate herself from the ronggeng and from the Kartarejas, she does not get a happy ending life, because of her meeting with Bajus who destroy her dream to be a wife and normal woman. he end of Srintil life in a very miserable condition and people just stare at her and mock her indicates that Srintil is a victim of ronggeng tradition. A "ronggeng" is admired when she is young and pleases many people, but she is scorned and mocked when she is in the miserable condition. This kind of admiration is not a real respect to human life. Such unrespectfulness to each other is the real tragedy of humanity.

\section{References}

Armstrong, Aurelia.Foucault and Feminism.University of Queensland. Retrieved 6 July 2013 from http://www.iep.utm.edu/foucfem/

Dabbas, K.J. 2009. Life Stories of Women Artists.

$\begin{array}{llll}\text { Retrieved } & 25 & \text { April } & 2009\end{array}$ http://www.ashgate.com/default.aspx?page $=1777 \&$ calcTitle $=1 \&$ pageSubject $=309 \&$ title_id $=7468$ \&edition_id $=9543$

Damono, S.D. 2005.Pegangan Penelitian Sastra.Jakarta: Pusat Pendidikan Nasional Pusat Bahasa Endraswara.

Suwandi. 2006. Metodologi Penelitian Sastra.Yogyakarta: Pustaka Widyatama 
Foucault, M. 1978. The History of Sexuality, translated by Robert Hurley, Vol. I, New York: Pantheon.

1988. Critical Theory/Intellectual Theory, interview with Gerard Raulet, in Kritzman, L. (ed.), Michel Foucault: Politics, Philosophy, Culture: Interviews and Other Writing, 1977-1984, London: Routledge.

Golden, A. 1997. Memoirs of Geisha. New York: Alfred A. Knopf.

Haryatmoko. 2013. Kekuasaan Melahirkan Anti-Kekuasaan: Paper pada Seminar series di Pascasarjana UGM. Yogyakarta.

Lips, M.H. 2003. A New Psychology of Women.American: Mc Graw Hill Mahayana, S.M.. 2013. Sastra Bandingan: Pintu Masuk Kajian Budaya Studi Kasus Romeo dan Julia, Sonezaki Shinju, Uda dan Dara. Retrieved 6 March 2013 from http://wahanasastra.blog.com/2010/11/17/sastra-bandingan-pintumasukkajian-budaya-studi-kasus-remeo-dan-yulia-sonezakishinju-uda-dan-dara/

Rahayu, M. 2009. Feminitas Geisha dalam Novel Arthur Golden, Memoirs of Geisha. Egalita: Jurnal Kesetaraan dan Keadilan Gender Vol.IV No.1 - UIN Malang.

Ratna, N.K. 2007. Estetika Sastra dan Budaya.Yogyakarta: Pustaka Pelajar.

Sasono, A. Pengakuan Geisha Modern: Sejarah Berubah. Retrieved 6 March $2013 \quad$ from http://nasional.kompas.com/read/2008/04/30/09031458/pengakua n.geisha.modern.sejarah.berubah accessed on Tuesday, march, 6 , 2013.

Segura, C. 2012 Scheduled post-Foucault and Marx. Retrieved 14 May 2013 from https://blogs.commons.georgetown.edu/engl-090fall2012/2012/10/29/scheduled-post-foucault-and-marx/

Suyono, S.J. 2002. Tubuh yang Rasis; Telaah Kritis Michel Foucault Atas Dasar-Dasar Pembentukan Diri Masyarakat Eropa.Yogyakarta: Pustaka Pelajar.

Thohari, A. 2003. Ronggeng Dukuh Paruk. Jakarta: PT Gramedia Pustaka.

Thohari, A. 2003. The Dancer. Trnsl. Rene T.A. Lysloff. Jakarta: Lontar 
Power Relation In Memoirs Of Geisha And The Dancer 